\title{
Multiple Regressions Analysis to investigate the optimal yield of Guava fruits at different level of NPK Fertilizers in south west Nigeria
}

\author{
Osuolale Peter Popoola ${ }^{1}$, Matthew Taiwo Odusina ${ }^{2}$, Wole Ayanniyi Ayanrinde ${ }^{3}$ \\ ${ }^{I}$ Mathematics and Statistics Department, Adeseun Ogundoyin Polytechnic, Eruwa. Oyo State, Nigeria \\ ${ }^{2}$ Mathematics and Statistics Department, Adeseun Ogundoyin Polytechnic, Eruwa. Oyo State, Nigeria \\ ${ }^{3}$ Mechanical Engineering Department, Adesun Ogundoyin Polytechnic, Eruwa. Oyo State, Nigeria
}

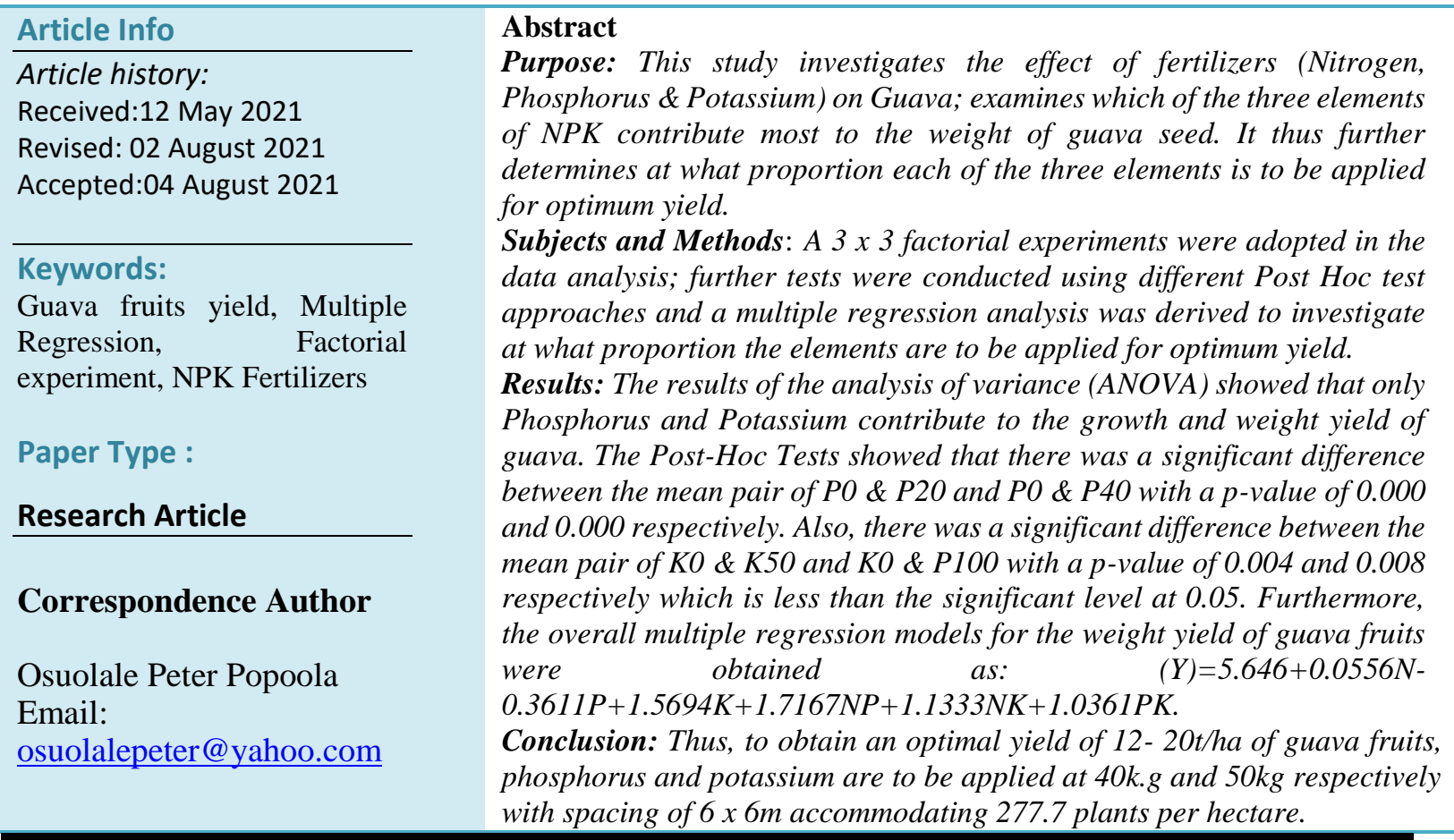

\section{Introduction}

Guava (Psidium guajava L.) is one of the important fruit crops. It belongs to the family Myrtaceae and is native to Tropical America stretching from Mexico to Peru, to Africa and indeed to Nigeria. Guava is a very popular fruit mostly used as a dessert fruit for its delicious taste and nutritive values. Presently, Brazil is the world's top producer of red guava. The Paluma cultivar is highly marketable in Brazil, featuring fine characteristics for both natural consumption and fruit industrialization. Furthermore, Paluma has adapted well to intensive production (which uses pruning, irrigation, and adjusted nutritional management). This allows production cycles of approximately eight months, well-suited for scheduling of fruit output. Guava is highly responsive to fertilization (Arova and Sngh, 1970), (Natale et.al., 1994, 2002), (Anjaneyulu and Raghupuhi, 2009). A whole array of tools is used to provide nutritional support, such as tissue and soil analyses (leaf analysis being the most reliable for assessing the nutritional status of perennial plants) grounded on adequate sampling methods 
and correct interpretation of analytical data (Bould et.al., 1960). These plants access nutrients at deeper depths than it would be possible to determine through standard soil analysis procedures. In evaluating plant nutritional status, standard nutrient contents are often criticized for not taking into due account interactions among elements (Bates, 1971). In natural systems, a ceteris paribus assumption (interactions between nutrients, in which all other factors remain constant) has its constraints, as double or multiple relations have been well-documented in plant nutrition studies (Fageria, 2001), (Malavolta, 2006). The effects of modifying nutrient proportions due to interactions among the nutrients were first illustrated by Lagatu and Maume (1935). Plant tissue data convey relative information, as they are intrinsically multivariate, i.e., no one component can be interpreted in isolation; it must be related to other components (Tolosana and Vanden, 2011). Hence, for compositional data (as in plant tissue nutrients), tools should be used that allow the analysis of inter-component interactions for the sake of better understanding of plant nutritional status. Compositional data analysis proposed by Aitchison (1982) has sparked wide-ranging discussion, given the practical importance of this new methodology, albeit some reluctance to its use remains to this day (Pawlowsky and Egozcue, 2001). Occasionally, this technique requires interpretation of results in terms of ratios and logarithmic proportions, which are harder to interpret than real vectors in statistical analysis. For the sake of simplifying analysis, components can be ordered to cluster them into two or more subsets, which are somehow easier to interpret (Egozcue and Pawlowski, 2005).

To avoid numerical bias in compositional analyses, Egozcue and Pawlowski-Glahn (2005) proposed using Isometric Log Ratios (ilr) based on the principle of orthogonality (D-1 degrees of freedom) to analyze compositional data. Isometric Log Ratios (ilr) coordinates can be projected onto Euclidian space, a geometric structure allowing analyses free from numerical bias (Egozcue and Pawlowski, 2011). An ilr transformation is a special log-transformation case that preserves the information contained in the new variable, allowing studies of relations among nutrients (Parent et. al., 2012). The ilr method is a three-stage method, namely: data represented in ilr coordinates; analysis of variance of the coordinates as real random variables; and interpretation of results in terms of balances (Egozcue and Pawlowski, 2011); they cannot, however, be transformed back into their initial values. Unlike conventional methodology, based on the contents of each nutrient, this tool is quite promising for the study of plant nutritional status in view of its sturdiness, and as it assesses nutrients taking into accounts the relations among them through nutrient balances. Hence, it is a more adequate instrument for this type of analysis. This concept has been successfully used in plant nutritional studies (Parent, 2011), (Hernandes et.al, 2012), as well as in soil aggregation (Parent et.al, 2012). Presuming that compositional data analysis is a robust tool to the interpretation of leaf analysis because it takes in consideration the relationship between nutrients.

The study aimed to improve the nutritional diagnosis of Paluma guava, evaluating rates of nitrogen and potassium fertilization in an irrigated commercial area for five consecutive cycles, with careful observation of the influence of fertilizers and the climate, using isometric $\log$-ratios. The nutrient requirement of guava differs from region to region due to soil support system, which imparts desired changes in growth and flushing in a set of climatic conditions. Guava crop is very responsive to the application of inorganic fertilizers. A balanced dose of NPK should be applied to the guava plants for normal growth and production (Mallick and Singh, 1960), (Singh and Singh, 2007). Nigeria lies between longitudes $2^{\circ} 49^{\prime} \mathrm{E}-14^{\circ} 37^{\prime} \mathrm{E}$ and 
latitudes $4^{\circ} 16^{\prime} \mathrm{N}-13^{\circ} 52^{\prime} \mathrm{N}$ and is in the humid tropics. It has a land area of $923,850 \mathrm{~km}^{2}$. In Nigeria, over 70 percent of the country's population is engaged in agriculture as their primary occupation and means of livelihood (Onwutube, 2019), (Shiru et.al, 2018), (Nkechi et.al, 2016), (Federal Ministry of Environment, 2014). Agricultural produce in Nigeria is mostly rain-fed. Unpredictable rainfall variation makes it difficult for farmers to plan their operations (Anabaraonye et al. 2019), (Chavez and Torres. 2012).

\section{Fertilizers and Guava}

The dispensable use of chemical fertilizers has widened soil imbalance in terms of NPK ratio and the overall decline in production capacity of the soil. Integration of organic substrates with chemical fertilizers can have a significant effect on the physical, microbiological and chemical properties of soil, which are responsible for supporting plant growth. The use of organic manures along with bio-fertilizers and crop residues is considered as a cheap source of available nutrients to plants which have beneficial effects on the growth, yield and quality of various fruit crops. Considering economy, energy and environment, plant nutrients should be caused effectively by adopting a proper nutrient management system to ensure high yield and to sustain the availability in the soil at an optimum level for getting higher yield and quality fruit production for which nutrient management is necessary. Scanty information is available on the effect of chemical fertilizers on the fruits yield of guava, hence the research work investigates the effect of fertilizers (Nitrogen, Phosphorus \& Potassium) on Guava; examines which of the three elements of NPK contribute most to the weight of guava seed. It thus further determines at what proportion each of the three elements is to be applied for optimum yield. Fertigation is commonly used for growing guavas in São Francisco Valley, due to it's a proven tool efficiency for uniform and balanced nutrient distribution since it provides water and nutrient availability in the higher root activity area of the plant canopy, especially if localized irrigation is used [28]. One of the nutrients applied through fertigation is nitrogen $(\mathrm{N})$ which is the second nutrient more required by guava tree and it is essential for plant growth and development, as an essential constituent of amino acids, enzymes, nucleic acids, and chlorophyll (Marschner, 2012).

A negative feature of $\mathrm{N}$ fertigation is possible groundwater contamination and $\mathrm{N}$ loss to the atmosphere, since plants are not able to absorb all $\mathrm{N}$ of the fertilizer. One possibility to mitigate $\mathrm{N}$ fertilizer excess is partial or total replacement by organic fertilizers such as bovine bio-fertilizer, which is an organic matter source able (or not) to supply $\mathrm{N}$ plant demand, it can also be supplied through fertigation, it is decomposed faster than solid fertilizers, has low-cost distribution and fast organic matter decomposition (Gross et al., 2009). Biofertilizer has positive effect soil physical and chemical characteristics (Pires et al., 2008) and consequently on plant growth and development, and, fruit production and quality. Especially for fruit quality it is registered in the scientific literature the biofertilizer effect on improving or maintaining fruit quality of yellow passion fruit custard apple (Leonel et al., 2015) and banana (Santos et al., 2014).

For guava compared organic and conventional production systems partially replaced by bio-fertilizer applied through fertigation and reported that bio-fertilizer was better than other treatments. Additionally, Batista et al. (2015) concluded that organic inputs use for growing 
guavas beyond synthetic inputs provides high fruit yield and fruit quality compatible to market demands for soluble solids, $\mathrm{pH}$, titra-table acidity, pulp firmness and soluble solids/titra table acidity ratio.

\section{Methodology and Procedures}

In practice, the response of biological organism to the factor of interest is expected to differ under different levels of other factors. For example the yield of wheat varieties may differ under different rates of fertilizers application, spacing and irrigation schedules. Thus when the effect of several factors is investigated simultaneously in a single experiment, such an experiment is known as a factorial experiment. The factorial experiment is an extension of the one-way ANOVA in that it involves the analysis of two or more independent variables. It is used in experimental designs in which every level of every factor is paired with every level of every other factor. It allows the researcher to assess the effects of each independent variable separately, as well as the joint effect or interaction of variables. Factorial designs are labeled either by the number of factor involved or in terms of the number of levels of each factor. Thus, a factorial design with two independent variables (e.g., gender and ethnicity) and with two levels for each independent variable (male/female; Australian/Chinese) is called either a two-way factorial or a $2 \times 2$ factorial.

In this experiment, there are three factors to be considered (Nitrogen, Phosphorus and Potassium) each at three levels of application at two replication i.e. The NPK fertilizers comprise of three elements namely Nitrogen, Phosphorus and Potassium with three levels: Nitrogen $(0,1,2)$, Phosphorus $(0,1,2)$ and Potassium $(0,1,2)$ Hence, a 3 x 3 factorial experiments were adopted. Various levels of the (NPK) fertilizer component in $(\mathrm{kg})$ : $\mathrm{N}=20.40$, $60 ; \mathrm{P}=0,20,40$; and $\mathrm{K}=0,50,100$.

\section{A 3 X 3 Factorial Fixed effect Model:}

$$
\begin{aligned}
Y_{i j k}=\mu+\tau_{i} & +\beta_{j}+\gamma_{k}+(\tau \beta)_{i j}+(\tau \gamma)_{i k}+(\beta \gamma)_{j k}+(\tau \beta \gamma)_{i j k} \\
& +\varepsilon_{i j k l}\left\{\begin{array}{l}
\mathrm{i}=1,2, \ldots, \mathrm{a} \\
\mathrm{j}=1,2, \ldots, \mathrm{b} \\
\mathrm{k}=1,2, \ldots, \mathrm{c} \\
\mathrm{l}=1,2, \ldots, \mathrm{n}
\end{array}\right.
\end{aligned}
$$

Where :

$\mu=$ is the overall mean

$\tau_{i}=$ is the effect of the ith level of Nitrogen

$\beta_{j}=$ is the effect of the $\mathrm{jth}$ level of Phosphorous

$\gamma_{k}=$ is the effect of the kth level of Potassium

$(\tau \beta)_{i j}=$ is the effect of the interaction between

$(\tau \gamma)_{i k}=$ is the effect of the interaction between Nitrogen and Potassium

$(\beta \gamma)_{j k}=$ is the effect of the interaction between Phosphorous and Potassium

$(\tau \beta \gamma)_{i j k}=$ is the effect of the interaction between Nitrogen, Phosphorous and

Potassium 
$\varepsilon_{i j k l}=$ is the random error component

Table 2.1: The Theoretical Analysis of Variance Table for Three-Factor Fixed Effects

Model

\begin{tabular}{|l|l|l|l|l|c|}
\hline $\begin{array}{l}\text { Source of } \\
\text { Variance }\end{array}$ & $\begin{array}{l}\text { Sum of } \\
\text { Square }\end{array}$ & $\begin{array}{l}\text { Degree of } \\
\text { Freedom }\end{array}$ & $\begin{array}{l}\text { Mean } \\
\text { Square }\end{array}$ & $\begin{array}{l}\text { Expected Mean } \\
\text { Square }\end{array}$ & $F_{0}$ \\
\hline A & $S S_{A}$ & a-1 & $M S_{A}$ & $\sigma^{2}+\frac{b c n \sum \tau_{i}^{2}}{a-1}$ & $F_{0}=\frac{M S_{A}}{M S_{E}}$ \\
\hline B & $S S_{B}$ & b-1 & $M S_{B}$ & $\sigma^{2}+\frac{a c n \sum \beta_{j}^{2}}{b-1}$ & $F_{0}=\frac{M S_{B}}{M S_{E}}$ \\
\hline C & $S S_{C}$ & c-1 & $M S_{C}$ & $\sigma^{2}+\frac{a b n \sum \gamma_{i}^{2}}{b-1}$ & $F_{0}=\frac{M S_{C}}{M S_{E}}$ \\
\hline AB & $S S_{A B}$ & $(\mathrm{a}-1)(\mathrm{b}-1)$ & $M S_{A B}$ & $\sigma^{2}+\frac{c n \sum \sum(\tau \beta)_{i j}^{2}}{(a-1)(b-1)}$ & $F_{0}=\frac{M S_{A B}}{M S_{E}}$ \\
\hline AC & $S S_{A C}$ & $(\mathrm{a}-1)(\mathrm{c}-1)$ & $M S_{A C}$ & $\sigma^{2}+\frac{b n \sum \sum(\tau \gamma)_{i k}^{2}}{(a-1)(c-1)}$ & $F_{0}=\frac{M S_{A C}}{M S_{E}}$ \\
\hline BC & $S S_{B C}$ & $(\mathrm{~b}-1)(\mathrm{c}-1)$ & $M S_{B C}$ & $\sigma^{2}+\frac{a n \sum \Sigma(\beta \gamma)_{j k}^{2}}{(b-1)(c-1)}$ & $F_{0}=\frac{M S_{B C}}{M S_{E}}$ \\
\hline Error & $S S_{E}$ & $a b c(n-1)$ & $M S_{E}$ & $\sigma^{2}$ & \\
\hline Total & $S S_{T}$ & $a b c n-1$ & & & \\
\hline
\end{tabular}

\section{Post Hoc Tests}

Post hoc tests are designed for situations in which the researcher has already obtained a significant omnibus F- test with a factor that consists of three or more means and additional exploration of the differences among means is needed to provide specific information on which means are significantly different from each other.

\section{Tukey`s HSD Test}

Tukey`s Honest Significance Difference (HSD) Test was designed for a situation with an equal sample size (the simplest adaptation uses the harmonic mean of n-sizes). Tukey`s test procedure makes use of the distribution of the standardized range statistic

$$
q=\frac{\bar{y}_{\max }-\bar{y}_{\min }}{\sqrt{\frac{M S E}{n}}}
$$

Where $y_{\max }$ and $y_{\min }$ are the largest and smallest sample means respectively out of the group of $\mathrm{p}$ sample means The formula for Tukey`s HSD equal sample is

$$
H S D=\sqrt[q]{\frac{M S E}{N}}
$$

Where $q=$ the relevant critical value of the standardized range statistic and $\mathrm{n}$ is the number of scores used in calculating the group mean interest.

\section{Results and Discussion}

\section{Table 3. 1. Summary of Data}




\begin{tabular}{|c|c|c|c|c|c|c|}
\hline Statistic & Minimum & $1^{\text {st }}$ Quarter & Median & Mean & 3rd Quarter & Maximum \\
\hline Value & 4.000 & 6.325 & 7.550 & 7.359 & 8.350 & 10.100 \\
\hline
\end{tabular}

Table 3.1 above shows the general summary of the data. It shows that the minimum value is 4.0 and the maximum value is 10.100 . The mean value is 7.359 while the median is 7.550. This implies that the data is negatively skewed, since the median value is greater than the mean value.

Table 3.2: Differences between Means between Groups of the Three Elements

\begin{tabular}{cllllrr}
\hline Elements & & Sum of Squares & df & Mean Square & F & Sig. \\
\hline \multirow{2}{*}{ Nitrogen } & Between Groups & 1.843 & 2 & .921 & .477 & .623 \\
& Within Groups & 98.428 & 51 & 1.930 & & \\
\hline \multirow{2}{*}{ Phosphorus } & Between Groups & 32.591 & 2 & 16.295 & 12.279 & .000 \\
& Within Groups & 67.680 & 51 & 1.327 & & \\
\hline \multirow{2}{*}{ Potassium } & Between Groups & 14.205 & 2 & 7.102 & 4.209 & .020 \\
& Within Groups & 86.066 & 51 & 1.688 & & \\
\hline & Total & 100.270 & 53 & & & \\
\hline
\end{tabular}

The table 3.2 above shows the mean difference between groups of three element of the fertilizer. It shows that there is significant difference between means of Phosphorus and Potassium across the three levels with their p-value of 0.000 and 0.020 respectively which is less than the pre-determine level of significance of 0.05 while there is no significant difference between the mean level of Nitrogen with a p-value of 0.623 which is greater than the predetermined level of significance of 0.05 . 


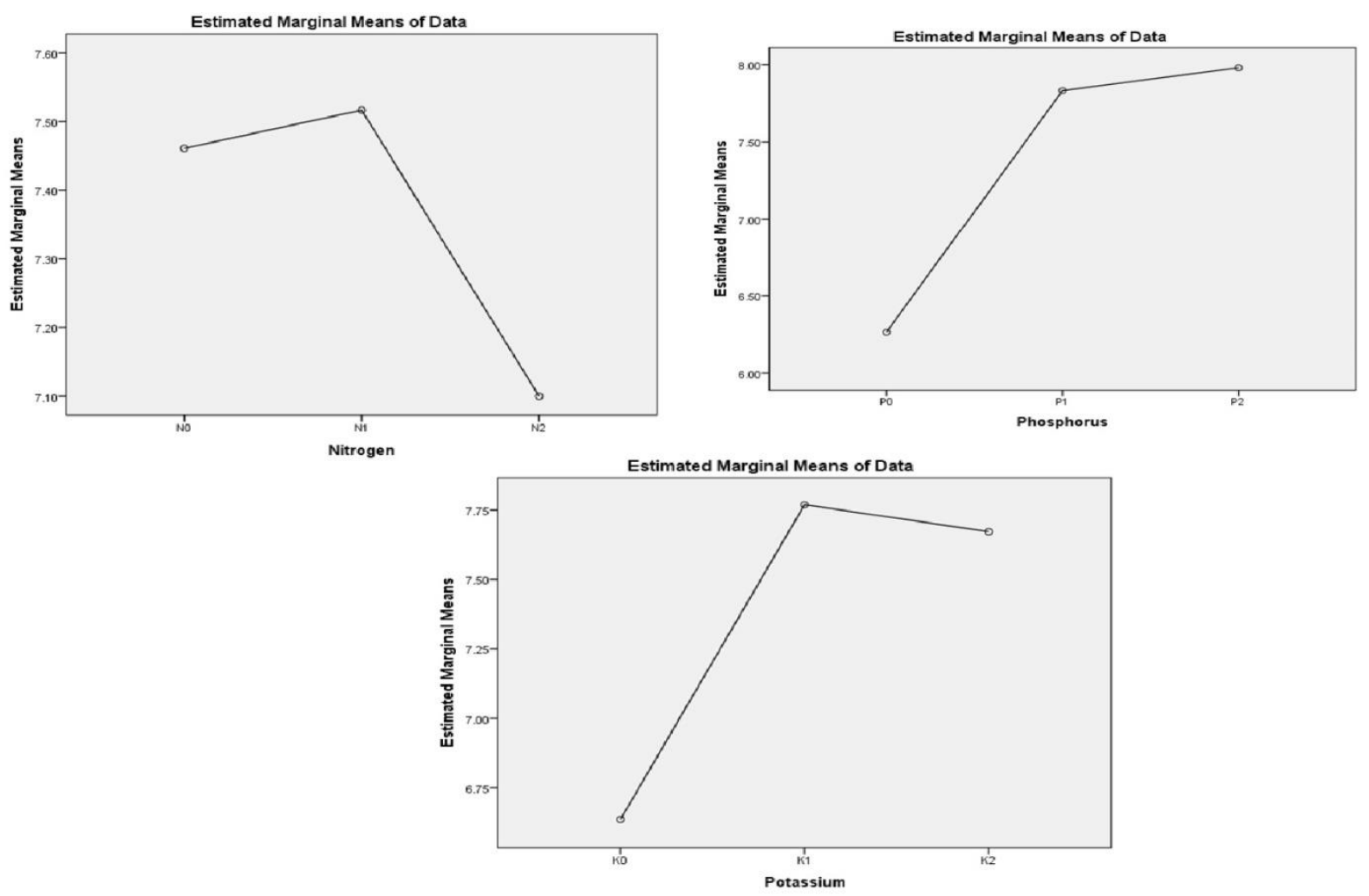

Figure 3.1. The graphical plot of the mean levels of the three elements of NPK fertilizers.

Table 3.3: The Result of ANOVA

\begin{tabular}{lllllll}
\hline Source & $\begin{array}{l}\text { Sum of } \\
\text { Square }\end{array}$ & df & \multicolumn{1}{c}{ Square } & F & Sig. & Remark \\
\hline Corrected Model & $67.983^{\mathrm{a}}$ & 26 & 2.615 & 2.187 & .024 & Sig. \\
Intercept & 2924.570 & 1 & 2924.570 & 2445.633 & .000 & Sig. \\
Nitrogen & 1.843 & 2 & .921 & .770 & .473 & N.Sig. \\
Phosphorus & 32.591 & 2 & 16.295 & 13.627 & .000 & Sig. \\
Potassium & 14.205 & 2 & 7.102 & 5.939 & .007 & Sig. \\
Nitrogen * Phosphorus & 1.150 & 4 & .287 & .240 & .913 & N.Sig. \\
Nitrogen * Potassium & 5.181 & 4 & 1.295 & 1.083 & .384 & N.Sig. \\
Phosphorus * Potassium & 5.502 & 4 & 1.375 & 1.150 & .354 & N.Sig. \\
Nitrogen * Phosphorus * Potassium & 7.513 & 8 & .939 & .785 & .620 & N.Sig. \\
Error & 32.288 & 27 & 1.196 & & & \\
Total & 3024.840 & 54 & & & & \\
Corrected Total & 100.270 & 53 & & & & \\
\hline
\end{tabular}

R Squared $=.678$ (Adjusted R Squared $=.368$ )

Table 3.3 above shows the result of ANOVA of Factorial Design of the effect of fertilizer on the weight of Guava Seed. From the table, it could be observed that the p-value for the model 0.024 is less than the pre-determined level of significance $(0.05)$ which implies that the model is adequately fit the data. Also, the intercept is highly significant with p-value 0.000 . Furthermore, there are significant differences between the mean level of Phosphorus and Potassium with their p-value of 0.000 and 0.007 respectively which is less than 0.05 , this 
implies that at least one pair of mean level is significant. Also, from the table above, it can be deduced that there is no significant difference in the mean level of Nitrogen as it p-value (0.473) is greater than the level of significance (0.05). In the same vein, it can be observed that there is no significant difference in the mean level of any of the interaction as their p-values are greater than the pre-determined level of significance of 0.05. This implies that applying Nitrogen and any of the possible combination will not influence the weight of Guava seed. The R-square gives 0.678 which implies that about $67.8 \%$ of the total variation in the observed variable can be accounted for by the ANOVA model.

Table 4 Post-Hoc Test for Phosphorus

\begin{tabular}{|c|c|c|c|c|c|c|}
\hline \multirow[t]{2}{*}{ (I) Phosphorus } & \multirow[t]{2}{*}{ (J) Phosphorus } & \multirow{2}{*}{$\begin{array}{c}\text { Mean } \\
\text { Difference (I- } \\
\mathrm{J})\end{array}$} & \multirow[t]{2}{*}{ Std. Error } & \multirow[t]{2}{*}{ Sig. ${ }^{b}$} & \multicolumn{2}{|c|}{$\begin{array}{l}\text { 95\% Confidence Interval for } \\
\text { Difference }\end{array}$} \\
\hline & & & & & Lower Bound & Upper Bound \\
\hline \multirow{2}{*}{ P0 } & P20 & $-1.569^{*}$ & .365 & .000 & -2.317 & -.822 \\
\hline & $\mathrm{P} 40$ & $-1.717^{*}$ & .365 & .000 & -2.465 & -.969 \\
\hline \multirow{2}{*}{$\mathrm{P} 20$} & $\mathrm{P} 0$ & $1.569^{*}$ & .365 & .000 & .822 & 2.317 \\
\hline & $\mathrm{P} 40$ & -.147 & .365 & .689 & -.895 & .601 \\
\hline \multirow{2}{*}{ P40 } & $\mathrm{P} 0$ & $1.717^{*}$ & .365 & .000 & .969 & 2.465 \\
\hline & P20 & .147 & .365 & .689 & -.601 & .895 \\
\hline
\end{tabular}

Table 3.4 above shows the post hoc test between the mean levels of Phosphorus. It can be deduced there is a significant difference between the mean pair of P0 \& P20 and P0 \& P40 with p-value of 0.000 and 0.000 respectively which is less than significant level 0.05 . Also, it can be observed that there is no significant difference between the mean levels of P20 \& P40 as its p-value 0.689 is less than 0.05 .

Table 3.5: Post-Hoc Test for Potassium

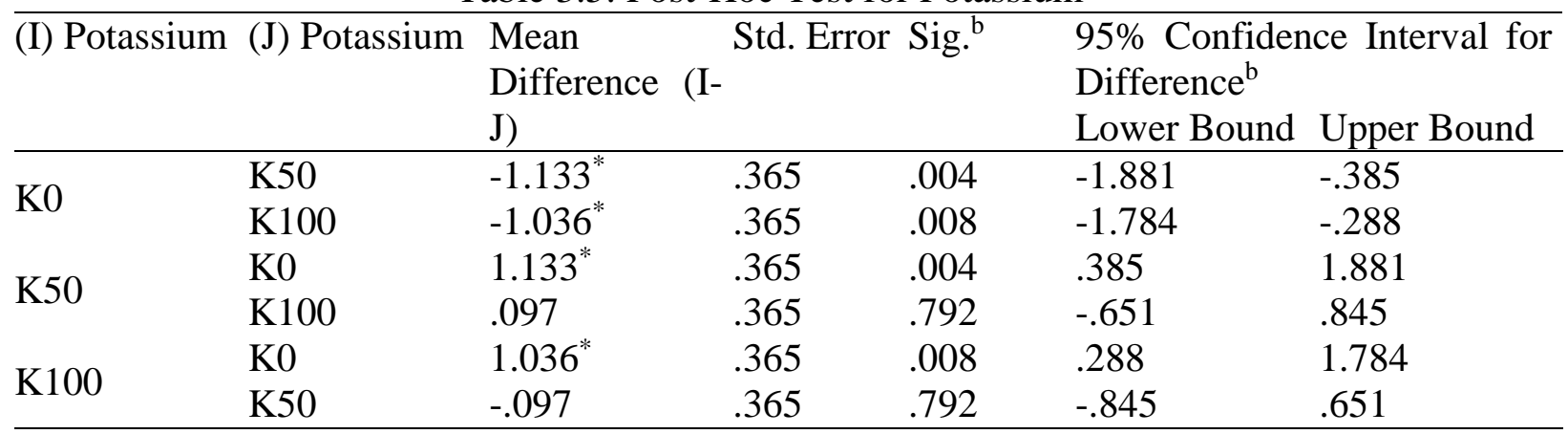

Table 3.5 above shows the post hoc test between the mean levels of Potassium. It can be deduced there is significance different between the mean pair of K0 \& K50 and K0 \& P100 with p-value of 0.004 and 0.008 respectively which is less than significant level 0.05 . Also, it can be observed that there is no significance difference between the mean levels of K100 \& $\mathrm{K} 50$ as its p-value 0.792 is less than 0.05 .

\subsection{Optimization of the application of NPK: Using Multiply Regression}

To obtain the optimal application of Phosphorous and Potassium the study employed the application of multiple regressions to determine the appropriate levels of the application of Phosphorous and Potassium for the fruit yield of Guava. 
General Multiple Regression Model:

$Y=\beta_{0}+\beta_{1} N i+\beta_{2} P_{i}+\beta_{3} K_{i}+e_{i}$

Where $\mathrm{Y}$ is the dependent variable, $Y=$ Guava fruit yield

$N_{i}, P_{i}$ and $K_{i}$ are independent variables; $\beta_{1}, \beta_{2}, \beta_{3}$ and $\beta_{4}$ are partially regression coefficients

$\beta_{o}$ is the intercept (mean effect of variable excluded from the model) and $e_{i}$ is the stochastic disturbance term.

Table 3.6: Summary of Model

\begin{tabular}{|c|c|c|c|c|c|c|c|c|c|c|}
\hline \multirow[t]{2}{*}{ Model } & \multirow[t]{2}{*}{$\mathrm{R}$} & \multirow{2}{*}{$\begin{array}{c}\mathrm{R} \\
\text { Square }\end{array}$} & \multirow{2}{*}{$\begin{array}{c}\text { Adjusted } \\
\mathrm{R} \\
\text { Square }\end{array}$} & \multirow{2}{*}{$\begin{array}{c}\text { Std. } \\
\text { Error of } \\
\text { the } \\
\text { Estimate }\end{array}$} & \multicolumn{5}{|c|}{ Change Statistics } & \multirow{2}{*}{$\begin{array}{l}\text { Durbin- } \\
\text { Watson }\end{array}$} \\
\hline & & & & & $\begin{array}{c}\mathrm{R} \\
\text { Square } \\
\text { Change }\end{array}$ & $\begin{array}{c}\mathrm{F} \\
\text { Change }\end{array}$ & df1 & df2 & $\begin{array}{c}\text { Sig. F } \\
\text { Change }\end{array}$ & \\
\hline & $.610^{\mathrm{a}}$ & .373 & .335 & 1.12172 & .373 & 9.897 & 3 & 50 & .000 & 2.015 \\
\hline
\end{tabular}

Table 3.6 above shows the summary of the model of the data. The p-value gives 0.000 which implies that the model is significant and adequately fit the data. The R-square gives 0.610 indicates that $61.0 \%$ of the total variation can be explained by the model leaving about $39.0 \%$ to be explained by other factors. The Dubbin Watson gives 2.015 which falls between 1.5 and 2.5 indicate that the data is not auto correlated.

Table 3.7.: Regression Model of the Data

\begin{tabular}{llllll}
\hline & Estimate & Std. Error & $\mathrm{t}$ value & $\operatorname{Pr}(>|\mathrm{t}|)$ & Remark \\
\hline (Intercept) & 5.64259 & 0.375 & 14.952 & 0.000 & Sig \\
$\mathrm{N}$ & 0.05556 & 0.469 & 0.159 & 0.874 & N.Sig \\
$\mathrm{P}$ & -0.36111 & 0.337 & -1.034 & 0.307 & Sig \\
$\mathrm{K}$ & 1.56944 & 0.343 & 4.492 & 0.000 & Sig \\
$\mathrm{N}^{*} \mathrm{P}$ & 1.71667 & 0.847 & 4.914 & 0.000 & N. Sig \\
$\mathrm{N}^{*} \mathrm{~K}$ & 1.13333 & 0.497 & 3.244 & 0.002 & N. Sig \\
$\mathrm{P}^{*} \mathrm{~K}$ & 1.03611 & 0.411 & 2.966 & 0.005 & Sig \\
\hline
\end{tabular}

The table 3.7 above shows the regression model of the weight of guava seed. The model is given as:

Weight of Guava seed $(Y)=5.646+0.0556 N-0.3611 P+1.5694 K+1.7167 N P+$ $1.1333 N K+1.0361 P K$

This implies that only Phosphorus and Potassium have a positive impact on the fruit of yield of guava. The combination of Potassium and Phosphorus contribute more to the model than any element. Also, it can be observed that only Nitrogen was not significant to the model with their p-value greater than 0.05 .

\section{Conclusion and Suggestion}

The results of various data analyses showed that: Phosphorus and Potassium contribute to the growth and weight yield of guava. Turkey's HSD test showed that there was a significant 
difference between the mean pairs of $\mathrm{P}_{0} \& \mathrm{P}_{20}$ and $\mathrm{P}_{0} \& \mathrm{P}_{40}$ with p-value of 0.000 and 0.000 respectively. Also, there was a significant difference between the mean pair of $\mathrm{K}_{0} \& \mathrm{~K}_{50}$ and $\mathrm{K}_{0} \& \mathrm{P}_{100}$ with a p-value of 0.004 and 0.008 respectively which is less than the significant level at 0.05 . Furthermore, the overall multiple regression models for the weight yield of guava fruits were obtained as: $(Y)=5.646+0.0556 N-0.3611 P+1.5694 K+1.7167 N P+$ $1.1333 N K+1.0361 P K$. Thus, to obtain an optimal yield of guava weight and fruit, phosphorus and potassium are to be applied at 40k.g and 50kg per hectare respectively.

\section{Conflict of Interest}

None declared.

\section{Funding:}

This study has not received any external funding.

\section{Data and Materials Availability}

All data associated with this study are presented in this paper.

\section{Peer-review}

External peer-review was done through double blind method.

\section{References}

Aitchison J. (1982). The statistical analysis of compositional data (with discussion). J Royal Stat Soc.;44:139-77.

Anabaraonye, B. et al. (2019). Educating farmers and fishermen in rural areas in Nigeria on climate change mitigation and adaptation for global sustainability. International Journal of Scientific \& Engineering Research, 10(4)1391-1398.

Anjaneyulu K, Raghupathi HB.( 2009). Identification of yield-limiting nutrients through DRIS leaf nutrient norms and indices in guava (Psidium guajava). Indian $\mathrm{J}$ Agric Sci.;79:418-21.

Arora JS, Singh JR. (1970). Effect of nitrogen, phosphorus and potassium sprays on guava (Psidium guajava L.). J Japan Soc Hortic Sci.;39:55-62.

Bates TE. (1971). Factors affecting critical nutrient concentrations in plant and their evaluation: a review. Soil Sci. 112:116-30.

Bould C, Bradfield EC, Clarke GM. (1960). Leaf analysis as a guide to the nutrition of fruit crops. General principles, sampling techniques and analytical methods. J Sci Food Agric.;11:229-42.

Chavez, J. C. L. and A. I. Z. Torres. (2012). Conventional guava in Zitacuaro's Region, Michoacan, Mexico. Sustain. Agric. Res. 1: 19-25 
Egozcue JJ, Pawlowsky-Glahn V. (2005). Groups of parts and their balances in compositional data analysis. Math Geol. 37:795-828.

Egozcue JJ, Pawlowsky-Glahn V. (2005). Groups of parts and their balances in compositional data analysis. Math Geol. 37:795-828.

Egozcue JJ, Pawlowsky-Glahn V. (2011). Análisis composicional de datos en ciencias geoambientales. Bol Inst Geol Miner. 122:439-52.

Egozcue JJ, Pawlowsky-Glahn V. (2011). Análisis composicional de datos en ciencias geoambientales. Bol Inst Geol Miner. 122:439-52.

Fageria VD. (2001). Nutrient interactions in crop plants. J Plant Nutr. 4:1269-90.

Federal Ministry of Environment (2014). United Nations Climate Change Nigeria. National Communication (NC). NC 2.

Gross, A., R. Arusi, P. Fine and A. Nejidat. (2008). Assessment of extraction methods with fowl manure for the production of liquid organic fertilizers. Bioresour Technol. 99: 327-334.

Hernandes A, Parent SE, Natale W, Parent LE. (2012). Balancing guava nutrition with liming and fertilization. Rev Bras Frutic. 34:1224-34.

Lagatu H, Maume L. (1935). The variations of the sum $\mathrm{N}+\mathrm{P}_{2} 0_{5}+\mathrm{K}_{2} 0$ per 100 parts of dry material of the leaf of a cultivated plant. Comp Rendus l'Acad D'Agric France. 21:8592.

Leonel, S., J. F. Araújo and M. A. Tecchio. (2015). Biofertilização e adubação organomineral: Concentração de nutrientes na folhae produtividade de frutos de pinheira. Irriga. 1: 40-51

Malavolta E. (2006). Manual de nutrição mineral de plantas. Piracicaba: Ceres.

Mallick, P.C. and Singh, D.L. (1960). Indian Agriculture. 4: 44-49.

Marschner, H. (2012). Mineral Nutrition of Higher Plants, 3rd ed. Academic Press, New York,

Natale W, Coutinho ELM, Boaretto AE, Pereira FM.(1994). La fertilisation azotée du goyavier. Fruits. 49:205-10.

Nkechi, O. et al. (2016). Mitigating climate change in Nigeria: African traditional religious values in focus. Mediterranean Journal of Social Sciences, 7(6), 299-308.

NY Batista, P. F., M. A. C. Lima, D. C. G. Trindade and R. E. Alves. (2015). Quality of different tropical fruit cultivars produced in the lower basin of the São Francisco Valley. Rev. Cienc. Agron. 46: 176-184.

Onwutuebe, C. J. (2019). Patriarchy and Women Vulnerability to Adverse Climate Change in Nigeria.

Parent LE, Parent SE, Rozane DE, Amorim DA, Hernandes A, Natale W. (2012). Unbiased approach to diagnose the nutrient status of red guava (Psidium guajava). Acta Hortic 959:145-59.

Parent LE, Parent SE, Rozane DE, Amorim DA, Hernandes A, Natale W. (2012). Unbiased approach to diagnose the nutrient status of red guava (Psidium guajava). Acta Hortic 959:145-59.

Parent LE. (2011). Diagnosis of the nutrient compositional space of fruit crops. Rev Bras Frutic.;33:321-34. 
Pawlowsky-Glahn V, Egozcue JJ. (2001). Geometric approach to statistical analysis on the simplex. Stochastic Environ Res Risk Assess. 15:384-98.

Pires, A. A., H. P. Monnerat, C. R. Marciano, L. G. R. Pinho, P. D. Zampirolli, R. C. Rosa and R. A. Muniz. (2008). Efeito da adubação alternativa do maracujazeiro amarelo nas características químicas e físicas do solo. Rev. Bras. Cienc. Solo. 32: 1997-2005.

Santos HG, Jacomine PKT, Anjos LHC, Oliveira VA, Oliveira JB, Coelho MR, Lumbreras JF, Cunha TJF. (2013). Sistema brasileiro de classificação de solos. $3^{\mathrm{a}}$ ed. Rio de Janeiro: Embrapa Solos.

Shiru, M.S., et al. (2018). Trend Analysis of Droughts During Crop Growing Seasons of Nigeria. Sustainability, 10(3), 871

Singh, H.P. and Singh, G.(2007). Nutrient and water management in guava. Proc. $1^{\text {st }}$ Interna. Guava Sym., CISH, Lucknow, Acta Hort., 735: 389-397.

Tolosana-Delgado R, van den Boogart KG.( 2011). Linear models with compositions in R. In. 